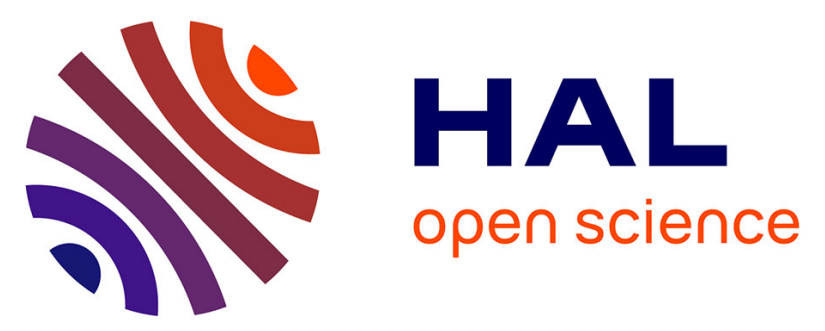

\title{
EVOLUTION OF LICIT AND ILLICIT DRUGS SINCE 1980 FROM A SEDIMENTARY ARCHIVE IN THE SEWER NETWORK OF ORLEANS (FRANCE)
}

Thomas Thiebault, Jérémy Jacob, Anaëlle Simonneau, Alexandre Thibault, Claude Le Milbeau, Rachel Boscardin, Pierre Sabatier, Luigi Ardito, Laurent Augustin, Laetitia Fougère, et al.

\section{To cite this version:}

Thomas Thiebault, Jérémy Jacob, Anaëlle Simonneau, Alexandre Thibault, Claude Le Milbeau, et al.. EVOLUTION OF LICIT AND ILLICIT DRUGS SINCE 1980 FROM A SEDIMENTARY ARCHIVE IN THE SEWER NETWORK OF ORLEANS (FRANCE). International Meeting on Organic Geochemistry, European Association of Organic Geochemists, Sep 2019, Göteborg, Sweden. insu-02308801

\section{HAL Id: insu-02308801 https://hal-insu.archives-ouvertes.fr/insu-02308801}

Submitted on 8 Oct 2019

HAL is a multi-disciplinary open access archive for the deposit and dissemination of scientific research documents, whether they are published or not. The documents may come from teaching and research institutions in France or abroad, or from public or private research centers.
L'archive ouverte pluridisciplinaire HAL, est destinée au dépôt et à la diffusion de documents scientifiques de niveau recherche, publiés ou non, émanant des établissements d'enseignement et de recherche français ou étrangers, des laboratoires publics ou privés. 


\section{EVOLUTION OF LICIT AND ILLICIT DRUGS SINCE 1980 FROM A SEDIMENTARY ARCHIVE IN THE SEWER NETWORK OF ORLEANS (FRANCE)}

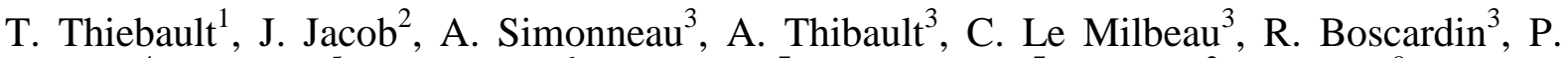

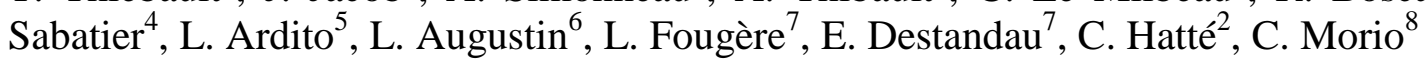

${ }^{1}$ Milieux environnementaux, transferts et interactions dans les hydrosystèmes et les sols, France

${ }^{2}$ Laboratoire des Sciences du Climat et de l'Environnement, France

${ }^{3}$ Institut des Sciences de la Terre d'Orléans, France

${ }^{4}$ Environnements, DYnamiques et TErritoires de la Montagne, France

${ }^{5}$ Bureau de Recherches Géologiques et Minières, France

${ }^{6}$ Centre de Carottage et de Forage National, France

${ }^{7}$ Institut de Chimie Organique et Analytique, France

${ }^{8}$ Orléans Métropole, France

\section{Introduction}

The Earth system is enduring a unique transition in its history due to the pregnancy of human activities on geological processes compared to natural controls. A large community examines the extent to which these activities will be archived in the sedimentary record and remain for millions years within a new geological era named Anthropocene. Here we explore the potential of sediments that accumulated in sewer systems for such a record of human posterity, considering that urban socio-ecosystems are prone to a large diversity and high concentrations of potential tracers of human activities.

\section{Site, materials and methods}

The selected site is a decantation tank that collects wastewater and stormwater from the sewer network of the northern part of Orléans (France). This $20 \mathrm{~m}$ deep underground building of cylindrical and conical shape was constructed in 1942 and was reputed to have not been subjected to any clean out operation (COO) since that time. This constitutes unique opportunity to study the evolution of a large variety of thematic involved in urban metabolism such as nutrition, health, transport, energy, practises, biodiversity... 6 cores were acquired from 2014 to 2017 in the $14 \mathrm{~m}$ depth sedimentary series. Five cores were retrieved by manually inserting a plastic tube in the outcropping sediments or with a gravity corer prior to COO. One core was obtained in the oldest and deepest sediments that remained after partial COO. All the $14 \mathrm{~m}$ sediments accumulated in the tank were collected by this mean. We focused our analyses on core CSA-02/2015-A that afforded the longest record. 90 sediment samples were directly extracted with (i) a mixture of water:methanol (1:1) in order to obtain drugs and illicit drugs that were then quantified by HPLC-MS ${ }^{2}$, (ii) a mixture of dichloromethane/methanol (9:1) for lipid biomarkers analyses using GC/MS. Extracted sediments then underwent a large range of classical sedimentological analyses (granulometry, facies description, microscopic description, mineralogy) and Total Organic Carbon, Hydrogen Index, Oxygen Index and Tmax were determined by Rock-Eval pyrolysis. The age model is based on $47{ }^{14} \mathrm{C}$ dates obtained on the 6 cores and computed with OxCal v4.3.2 and Bomb13NH1 calibration curve.

\section{Results and discussion}

Oldest sediments are dated back to 1970. This reveals that COO certainly took place at the end of the seventies, with no administrative or written record subsisting. Sedimentation rates are then very high with $6 \mathrm{~m}$ deposited in two years, which corresponds to accumulation rates 
observed after the 2015 COO. Then, sedimentation rates slowed down with only $2.5 \mathrm{~m}$ accumulated from 1980 to 2014 because the decantation tank was saturated and could not accumulate more sediments. Hence, repeated episodes of erosion compensated by deposition are suspected over that period. Sediments are stratigraphically organised into organic (TOC > $2 \%$ ) and mineral (TOC $<2 \%$ ) layers resulting from wastewater and stormwater inputs, respectively.

Concentrations of 27 drugs and illicit drugs were measured in 90 samples on core CSA02/2015-A that records the 1980-2010 time period. Some compounds such as ciprofloxacin, ofloxacin or tetrahydrocannabinol could not be detected in the sediments. For the other detected compounds, a strong control of speciation on the presence and concentration of drugs and illicit drugs is evidenced. Neutral and anionic compounds (e.g. carbamazepine, salicylic acid) present higher concentrations in the lower part of the core whereas cationic compounds (e.g. codeine, benzoylecgonine) display higher concentrations in the upper part. For the formers, their distributions are directly correlated with the distribution of organic carbon, whereas for the latters, a correlation with the relative abundance of inorganic surfaces is evidenced. As a result, the interaction mechanisms between targeted compounds and the sedimentary composition appears to be the most important control of their occurrences. Finally, for some compounds such as cocaine and MDMA, the concentration decreases with the depth, indicating a degradation pattern. This type of pattern is emphasized by the relative increase of the benzoylecgonine/cocaine ratio with depth (i.e. benzoylecgonine is one of the main metabolite of cocaine).

\section{Conclusion}

The analysed sediments present important vertical variations of composition, due to distinct origin, especially emphasized by the organic carbon variations. Hence, drugs and illicit drugs distributions appear to be strongly controlled by their affinity with bearing phases. As a result, the distribution of these compounds with time cannot be directly correlated with the evolution of excretion amount in the catchment, as expected. Nevertheless, these patterns are very informative on the affinity between sediments and organic contaminants at a larger scale. 